\title{
Corrosion resistance of the microarc oxidation coatings prepared on magnesium alloy
}

\author{
Ying Lv, Jun Gang Li* ${ }^{*}$ Ming Zhong Wu, Zhen Ma, Jing Qiang Zhang, and Le Le Wang \\ School of Materials Science and Engineering, Jiamusi University, Jiamusi154007, China
}

\begin{abstract}
Ceramic coatings were prepared on the surface of AZ91D magnesium alloy by microarc oxidation technology. The effects of different voltages on morphology, phase composition and thickness of the coatings were characterized by SEM and XRD. The corrosion resistance of the coatings was measured by electrochemical workstation. Results indicated that the microarc oxidation coatings prepared in sodium silicate electrolyte exhibited porous surface and mainly comprised $\mathrm{MgO}, \mathrm{Mg}_{2} \mathrm{SiO}_{4}$ and a small amount of $\mathrm{MgAl}_{2} \mathrm{O}_{4}$. The thickness of the oxide coatings increased rapidly with the increase of voltage. The coating prepared at $400 \mathrm{~V}$ voltage had good electrochemical corrosion resistance in $3.5 \mathrm{wt} \% \mathrm{NaCl}$ solution.
\end{abstract}

\section{Introduction}

In light metal structural materials, magnesium alloys possess many excellent properties such as high specific strength, good electric conductivity and thermal conductivity, vibration damping, electromagnetic shielding, easy processing molding and recycling use [1]. Therefore, they have wide prospect in the fields of electronic industry, aerospace, automobile, biomedicine, etc. However, magnesium alloys have poor corrosion resistance and high-temperature resistance. The standard electrode potential of pure magnesium is only $-2.37 \mathrm{~V}$, which is the lowest in all the structural metals[2]. The oxide film formed on the magnesium surface in the air has porous structure, resulting in the poor protection for the substrate[3]. So magnesium alloys are not suitable for most corrosive environments, which has restricted their widespread applications.

The use of surface treatment technology can improve the properties of magnesium alloys[4]. Microarc oxidation (MAO) is a new nonferrous metal surface modification technique developed on the basis of anodic oxidation[5,6]. Under the action of a strong electric field, the gas in the electrolyte is ionized, and the microarc discharge is produced[7]. As a result, the ceramic oxide coating in-situ forms on the surface of nonferrous metal such as $\mathrm{Al}$, Ti and $\mathrm{Mg}$. MAO has the advantages of simple process, high efficiency and low pollution, which has became the most potential surface treatment technology for magnesium alloys[8]. In the present study, ceramic coatings were obtained on the surface of AZ91D magnesium alloy by the MAO technology. The effects of different voltages on morphology, microstructure and thickness of the MAO coatings were studied, and the corrosion resistance of the coatings was also investigated.
The substrate material was AZ91D magnesium alloy ingot which was cut into the samples with a dimension of $20 \mathrm{~mm} \times 15 \mathrm{~mm} \times 3 \mathrm{~mm}$ by line cutting device. Every sample was drilled a hole with $2 \mathrm{~mm}$ in diameter, then ground with 200, 400, 600 and 800 mesh SiC sandpapers step by step, finally immersed into the acetone and cleaned $3 \mathrm{~min}$ by ultrasonic washing machine.

An alkaline electrolyte was prepared from the deionized water solution of $\mathrm{Na}_{2} \mathrm{SiO}_{3} \cdot 9 \mathrm{H}_{2} \mathrm{O}(20 \mathrm{~g} / \mathrm{L})$, $\mathrm{NaOH}(5 \mathrm{~g} / \mathrm{L})$ and $\mathrm{C}_{3} \mathrm{H}_{8} \mathrm{O}_{3}(10 \mathrm{~mL} / \mathrm{L})$. A bipolar pulsed power supply produced by Harbin Institute of Technology was used to fabricate the MAO coating. The stainless steel electrobath was as the cathode. The samples, suspended with aluminum wire, were immersed in the electrolyte as the anode. The experiments were carried out under constant voltage mode with frequency of $400 \mathrm{~Hz}$ and duty ratio of $8 \%$. The voltage was adjusted to $350 \mathrm{~V}, 400 \mathrm{~V}$, and $450 \mathrm{~V}$, respectively. The temperature of the electrolyte was controlled under $38^{\circ} \mathrm{C}$. After the samples were oxidized for $15 \mathrm{~min}$, closed the power, then removed the samples. The preparation process of the MAO coatings was shown in Fig.1.

\section{Results and discussion}

\subsection{Phase composition of the MAO coating}

XRD pattern of the MAO coating fabricated at $400 \mathrm{~V}$ voltage was shown in Fig.2. The coating was mainly composed of $\mathrm{MgO}, \mathrm{Mg}_{2} \mathrm{SiO}_{4}$ and a small amount of and $\mathrm{MgAl}_{2} \mathrm{O}_{4}$. In the process of $\mathrm{MAO}$, the oxidation reaction of the magnesium substrate and oxygen produced $\mathrm{MgO}$ under the action of arc, then $\mathrm{Mg}_{2} \mathrm{SiO}_{4}$ was generated owing to the participation of the electrolyte.

\section{Experimental}

\footnotetext{
* Corresponding author: $89211071 j g @ 163 . c o m$
} 


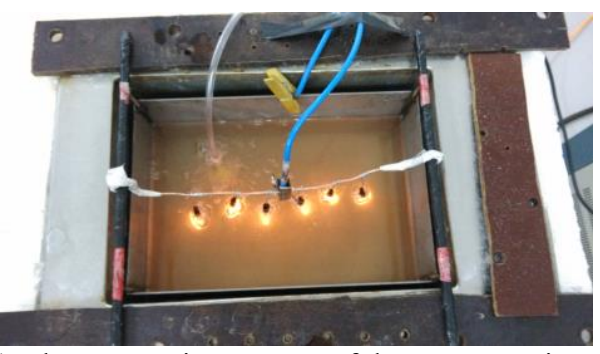

Fig. 1. The preparation process of the MAO coatings.

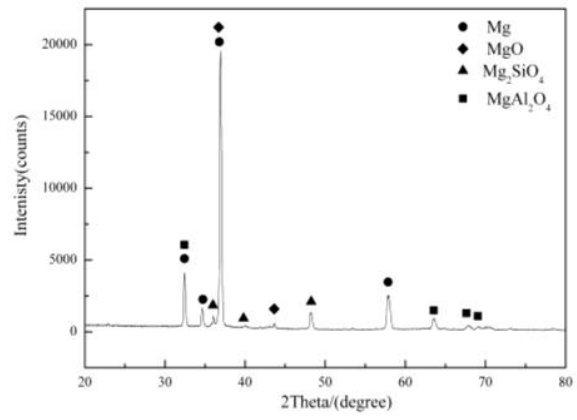

Fig. 2. Phase composition of the coating fabricated at $400 \mathrm{~V}$.

\subsection{Morphology of the MAO coating}

The morphology of the MAO coating fabricated at different voltages was represented in Fig.3 5. It was found that the surface layer of the MAO coatings had porous structure with irregular micropores. When the voltage was $350 \mathrm{~V}$, the arc was so weak that electric breakdown occurred in the same position for a long time. As a result, the layer surface was uneven and distributed $2 \sim 15 \mu \mathrm{m}$ diameter micropores. There were some protuberances around the micropores, as shown in Fig. 3. When the voltage was $400 \mathrm{~V}$, the arc starting was stable and fine, so the layer surface was smooth with uniform micropores of $2 \sim 5 \mu \mathrm{m}$ diameter, as shown in Fig. 4. When the voltage was raised to $450 \mathrm{~V}$, the arc starting was acute and the arc became thicker. Consequently, the molten substances that sprayed out along the arc channel were on the increase, which made the surface rougher, as shown in Fig. 5.

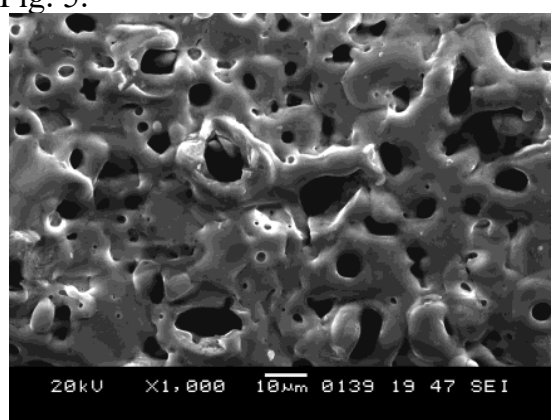

Fig. 3. Morphology of the MAO coating fabricated at $350 \mathrm{~V}$

The thickness of the MAO coatings was illustrated in table.1. It could be seen that the thickness of the coatings increased with the voltage. When the voltage was $450 \mathrm{~V}$, the coating was the thickest with $16.4 \mu \mathrm{m}$.

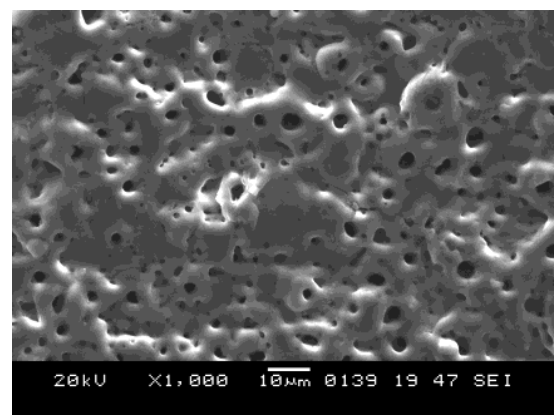

Fig. 4. Morphology of the MAO coating fabricated at 400V.

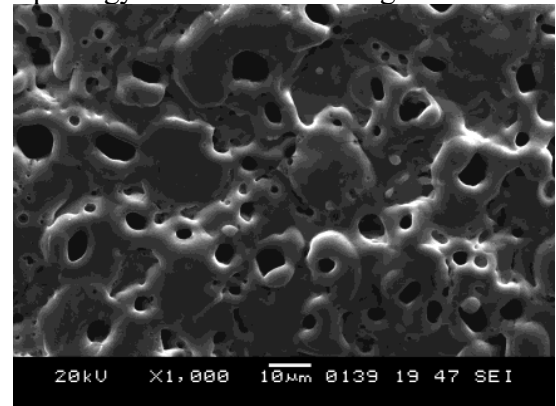

Fig. 5. Morphology of the MAO coating fabricated at $450 \mathrm{~V}$.

Table 1. The thickness of the MAO coating.

\begin{tabular}{|c|c|c|c|}
\hline Voltage $(\mathrm{V})$ & 350 & 400 & 450 \\
\hline $\operatorname{Thickness}(\mu \mathrm{m})$ & 10.1 & 14.2 & 16.4 \\
\hline
\end{tabular}

\subsection{Formation process of the MAO coating}

After the AZ91D alloy was placed in the electrolyte and electrified, a thin insulated oxide film formed immediately on the substrate surface. Once the voltage applied on the samples exceeded a certain critical value, some weak portions on the oxide film were broken down and microarc discharge occurred. The impact of arc on the substrate surface resulted in a severe oxidation reaction, releasing a large amount of gas. The reactions generated in the electrolyte were as follows:

$$
\begin{gathered}
\mathrm{Mg} \rightarrow \mathrm{Mg}^{2+}+2 \mathrm{e} \\
\mathrm{Al} \rightarrow \mathrm{Al}^{+}+3 \mathrm{e} \\
\mathrm{O}^{2}+4 \mathrm{e} \rightarrow 2 \mathrm{O}^{2-} \\
\mathrm{Mg}^{2+}+\mathrm{O}^{2-} \rightarrow \mathrm{MgO} \\
\mathrm{Mg}^{2+}+\mathrm{H}_{2} \mathrm{O} \rightarrow \mathrm{MgO}+\mathrm{H}_{2} \uparrow \\
2 \mathrm{Al}^{3+}+3 \mathrm{H}_{2} \mathrm{O} \rightarrow \mathrm{Al}_{2} \mathrm{O}_{3}+3 \mathrm{H}_{2} \uparrow \\
2 \mathrm{Mg}^{2+}+\mathrm{SiO}_{3}^{2-}+\mathrm{O}^{2-} \rightarrow \mathrm{Mg}_{2} \mathrm{SiO}_{4} \\
\mathrm{Mg}^{2+}+\mathrm{Al}_{2} \mathrm{O}_{3}+\mathrm{O}^{2-} \rightarrow \mathrm{MgAl}_{2} \mathrm{O}_{4}
\end{gathered}
$$

Under the action of the arc, the molten $\mathrm{MgO}$, $\mathrm{MgAl}_{2} \mathrm{O}_{4}$ and a small amount of $\mathrm{MgAl}_{2} \mathrm{O}_{4}$ were mixed together. Due to high temperature, large amounts of $\mathrm{H} 2$ in the arc channel produced high pressure which helped above mixture to eject from the arc channel and accumulate around the channel. Ultimately, owing to the rapid cooling of the electrolyte, molten mixture solidified and produced circular protuberances covering on the AZ91D alloy surface.

In the MAO process, the thickness of the coatings changed constantly. When the voltage was $350 \mathrm{~V}$, the 
coatings became thicken, which caused arc starting to be weaker. Arc was only generated at local position for a long time, therefore many large diameter arc channel appeared. When the voltage was $400 \mathrm{~V}$, the arc starting was uniform and the arc position changed frequently. Fine arc could transfer rapidly in all the positions, so the arc channel formed had relatively small diameter. When the voltage was $450 \mathrm{~V}$, the arc became thicker and its duration prolonged, causing the increase of the ejected mixture and the height of the protuberances around the arc channel. Ultimately, the oxide coating was formed on the surface of AZ91D alloy under the action of arc. With the increase of oxidation time, the oxide coatings became thicker and had good bonding with the substrate.

\subsection{Electrochemical corrosion analysis of the MAO coating}

Fig. 6 presented the dynamic polarization curve of the MAO coatings prepared at different voltages in $3.5 \mathrm{wt} \% \mathrm{NaCl}$ solution. The corrosion potential and corrosion current of the coatings were shown in Table 2.

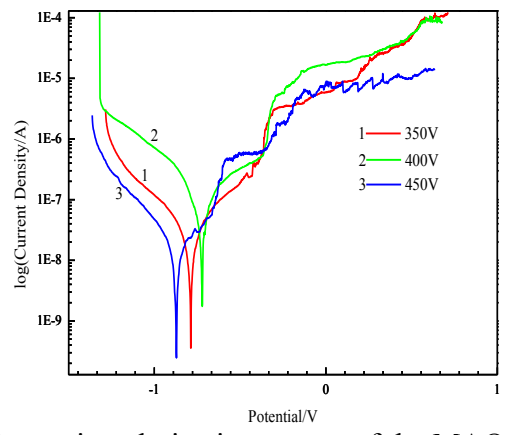

Fig.6. Dynamic polarization curves of the MAO coating.

Table 2. Electrochemical corrosion current and potential.

\begin{tabular}{|c|c|c|c|}
\hline $\begin{array}{c}\text { Voltage } \\
(\mathrm{V})\end{array}$ & 350 & 400 & 450 \\
\hline $\begin{array}{c}\text { Corrosion } \\
\text { potential } \\
(\mathrm{mV})\end{array}$ & -780.755 & -734.353 & -852.568 \\
\hline $\begin{array}{c}\text { Corrosion } \\
\text { current } \\
(\mathrm{mA})\end{array}$ & $\begin{array}{c}8.348 \\
\times 10^{-5}\end{array}$ & $\begin{array}{l}2.385 \\
\times 10^{-4}\end{array}$ & $\begin{array}{l}1.173 \\
\times 10^{-4}\end{array}$ \\
\hline
\end{tabular}

During the electrochemical corrosion, the cathode polarization mainly involved hydrogen evolution process in which the $\mathrm{H}^{+}$in the solution had been replaced by $\mathrm{Mg}$. Anodic polarization referred to the active dissolution of $\mathrm{Mg}$ alloy, that is, $\mathrm{Mg}^{2+}$ and $\mathrm{Al}^{3+}$ transferred from the substrate to the $\mathrm{NaCl}$ solution and produced hydrated cations. According to Fig. 6, a buffer platform of corrosion current density appeared in curve 2 and curve 3 in the anodic polarization process, and this anodic passivation phenomenon was benefit for the improvement of the corrosion resistance. When the voltage was $400 \mathrm{~V}$, the MAO coating exhibited the lowest corrosion current and the highest corrosion potential, indicating that its corrosion resistance was best of all the MAO coatings.
The MAO coatings prepared on AZ91D alloy exhibited porous surface and mainly comprised $\mathrm{MgO}, \mathrm{Mg}_{2} \mathrm{SiO} 4$ and a small amount of $\mathrm{MgAl}_{2} \mathrm{O}$. When the voltage was $400 \mathrm{~V}$, the coating had the best surface quality with small and uniform micropores. The thickness of the oxide coatings increased rapidly with the increase of voltage. The thickness of the coating was $10.1 \mu \mathrm{m}$ at $350 \mathrm{~V}$ and $16.4 \mu \mathrm{mm}$ at $450 \mathrm{~V}$. When the voltage was $400 \mathrm{~V}$, the MAO coating obtained the lowest corrosion current and the highest corrosion potential, indicating that its corrosion resistance was best of all the MAO coatings.

\section{Acknowledgements}

This work was supported by the Basic Scientific Research Foundation of Heilongjiang Provincial Education Department (2016-KYYWF-0552), Key Scientific Research Foundation of Jiamusi University (Lz2013-013) and Open Foundation of University Key Laboratory of Biomaterial (YB12001). The authors thank the Engineering Center for Wear Resistant Materials and Surface Technology of Ministry of Education (Jiamusi University).

\section{References}

1. G. Wu, K.C. Chan, L.L. Zhu, L. Sun, J Lu, Nature, 545 (2017)

2. A. Pardo, M.C. Merino, M. Mohedano, P. Casajús, A.E. Coy, R. Arraba, Surf. Coat. Technol. 203 (2009)

3. Y.H. Sun, R.C. Wang, C.Q. Peng, Y. Feng, M. Yang, T. Nonferr. Metal. Soc. 27 (2017)

4. Y.J. Zhang, C.L. Zhao, S. Tao, S.G. Jia, Z.C. Liu, Appl. Mech. Mater. 713 (2015)

5. X.J. Cui, X. Dai, B.Y. Zheng, Y. Zhang, J. Chin. Soc. Corros. Prot. 37 (2017)

6. L.Y. Cui, S.D. Gao, P.P. Li,R.C. Zeng, F. Zhang, Corros. Sci. 118(2017)

7. B. Zou, G.H. Lu, G.L. Zhang, Y.Y. Tian, T. Nonferr. Metal. Soc. 25 (2015)

8. M. Tang, Z. Feng, G. Li, Z. Zhang, R. Zhang. Surf. Coat. Technol. 264(2015) 